\title{
News Framing and Ethnic Conflicts Vulnerability in Multiethnic Societies
}

\author{
Adisa, Rasaq M. \\ Doctoral Candidate at the dept. of Communication, Sch. of Multimedia Technology and Communication \\ Universiti Utara Malaysia; adisarasaqm@yahoo.com
}

\section{Rosli bin Mohammed PhD}

Senior Lecturer and Dean, Sch. of Multimedia Technology and Communication

Universiti Utara Malaysia, roslimohd@uum.edu.my

Mohd. Khairie Ahmad PhD

Senior Lecturer and Head, Dept. of Communication, Sch. of Multimedia Technology and Communication Universiti Utara Malaysia; khairie@uum.edu.my

\section{Doi:10.5901/mjss.2015.v6n6s1p496}

\section{Abstract}

The springboard of conflicts in most multiethnic African societies have been alluded to the media and ethnic group leaders, however much attention has not been directed at these helixes. More so that there is a new strong concern about the increasing cases of ethnic conflicts being stimulated by dramatic surge in intolerant expressions, the hardening of ethnopolitical positions and the proliferation of ethnic militias that have unleashed varying degrees of violence and terror on the polity while the government interventions appeared ineffective. This motivates the main objective of this study which goes beyond understanding the immediate motives for ethnic conflicts in Nigeria but to discover the mainsprings of ethnic conflict behaviour in relation to the roles of newspaper framing and ethnic groups' attitudes alongside a long lasting solutions. Therefore, series of accusations against the Nigeria newspapers by the ethnic group leaders lead us to understand that the media are indeed insensitive on the issues of ethnic conflict. Also, that from bias framing of ethnic issues, newspapers have enormous power in setting ethnic differences which shape conflict behaviour. Another salient but veiled influences emanating from the findings are the ethnic consciousness and intolerance that have continued to impede the relationship among ethnic groups as well as progress of Nigeria. Due to high level intolerance for each other, every action and inaction is given ethnic coloration as a result conflict ensue. Meanwhile, both government and media self-regulation should be strengthened to curb the excesses that stimulate ethnic conflicts. Hence, how the newspaper presents news of ethnic issues should be a direction for future research.

Keywords: Framing, ethnic groups, conflict behaviours, ethnic conflict, newspaper

\section{Introduction}

Ethnic conflict has been at the core of Nigeria development problems (Bienen, 2013; Irobi, 2005), therefore the inability to prevent and stop prevalent ethnic conflicts in several regions of the country has given rise to strong concern and at the same time stimulating new interest in ethnic conflicts research (Onwusuruibgo, 2010). Meanwhile, the springboard of conflict in most multiethnic societies have been identified as the media and ethnic group leaders (McBeath, 1978; Straus, 2007; Wiegenstein, 2014) however, research attention towards these areas is inadequate (Hutchison, 2013). What is surprising is the relative paucity of studies on the roles that ethnic group leaders in conjunction with the role that framing in newspaper play as the helix of these conflicts. In view of this therefore, some of the critical gaps which this study addresses, are what Hutchison (2013) describes as inadequate research attention that is devoted to ascertaining factors responsible for changes in individual attitudes and behavior that eventually lead to conflict.

In the case of Nigeria, it has demonstrated a very high propensity for ethno-political conflict in the past three decades (Ojo, 2010). However, in more recent times, there has been a dramatic surge in intolerant expressions, the hardening of ethno-political positions and the proliferation of ethnic militias that have unleashed varying degrees of violence and terror on the polity (Egwu, 2001). In spite of concerted efforts being made to curtail it, the problem has escalated, especially since the return of democracy in May 1999. Such that in all parts of Nigeria and Africa, ethnopolitical conflicts have escalated to alarming proportions (Adisa \& Abdulraheem, 2012; Halirru, 2012). A case in point was 
the conflict behaviours that pave the way for the 1994 Rwanda genocide that was obviously wrapped in ethnic animosity but was ignored by the locals, neighbors and international communities until it claimed over 800,000 lives (Eytan, Munyandamutsa, Nkubamugisha, \& Gex-Fabry, 2014; Serneels, \& Verpoorten, 2013). Similar insolences and consequences were experienced in Ethiopia, Bosnia from 1992 - 1995 and recently in Central African Republic and Darfur since 2003 and now in Southern Sudan (even with secession in 2011) to the peril of all citizens and neighbouring countries. It has been cases of old conflicts worsen, new ones surfacing (Arbour, 2014). This is why the main objective of this study goes beyond understanding the immediate motives for conflicts behaviours in Nigeria but to discover the mainsprings of ethnic conflict in relation to the roles of newspaper framing and ethnic groups alongside a long lasting solutions.

\section{Ethno-political Conflicts in Africa and Framing Theory}

The concept of framing has been one of the most abundant areas in recent research in communication, politics and sociology because framing can clarify and interpret the extent the media affect publics' understanding of politics (Lecheler \& De Vreese, 2012). Earlier, framing theory has its origins in politics and psychology, but was later applied in the study of how journalists shape and control news by scholars like Todd Gitlin and Gaye Tuchman in the late 1970s (Karnes, 2008). Ever since that time several researchers on the impact of news coverage have come up with many overview of framing. Scholars (de Vreese, Boomgaarden, \& Semetko, 2011; de Vreese, 2005; Kostadinova \& Dimitrova, 2012) have declared that the concept of framing has become one of the most used concepts in the communication disciplines, giving direction to both inquiries of media content and examination of the connection between media and public opinion. Similarly, Bryant and Miron (2004) admit that presently framing concept has moved beyond agenda-setting and cultivation theory as the most frequently applied research approach in the field of communication science.

Previous studies of framing have concentrated much on political framing of candidates mostly in the western world during elections however, this research sifts attention to both newspaper framing of conflicts and ethnic groups' behaviours in Nigeria, the largest country in Africa continent. In relation to this, de Vreese (2005) reassures that framing is a foremost guidance to research on media contents and the studies of connection between media and public opinion. Therefore, Reese (2001) concludes that framing studies probing news media can provide understanding on how a certain society or culture is potentially shaped.

In relation to this, Jeong (2008) hints that handling and stopping conflict as well as understanding the basis of conflict and related behaviour begins with understanding the sources of social struggles. Also, according to Munteanu (2011) the relation between conflict prevention and the media is still an unexplored issue. Seriki (1993) confirmed that the 1991 Katshina riot in Nigeria was connected with a newspaper framing. Also, part of the blame for the unprecedented conflict behaviours among Hausa/Beron ethnic groups in the yet to be abated violent conflict in Jos have been partially blamed on the press, (Daily Independent, 2010; The Vanguard of 2010). Establishing this fact further Nnaemeka (1976) notes that newspapers' and other media's reports of conflict are contributory to the legitimating of conflict. The view was shared by Ibrahim, Pawanteh, Peng Kee, Basri, Hassan and Mahmud (2011) that for a long time news media have been participants in the spectacle of war and conflicts.

Similarly in several studies, mass media (and other forms of communication) were implicated in the escalation of conflicts and later on in the potential de-escalation (Erni, 2009; Leung, 2009; Spencer, 2005). This incidents confirm the framing postulation that how an issue is described in news story can sway how it is understood by audiences (Van Gorp, 2007). Clarifying the uniqueness of framing further, Entman (1993) maintains that framing has four core functions which are: describing problems, identifying causes, making proper judgments, and then proposing remedies. Framing theory offers the basis for understanding how conflict is reported in newspapers (Carpenter, 2007) because according to de Vreese (2005), de Vreese, Boomgaarden, and Semetko (2011), a frame is an emphasis in salience of various aspects of an issue such as conflict. Also, according to Zhou (2008) scholars use the concept of framing as an instrument to appreciate news as a social construction and social resource. To Shoemaker and Reese (1991) during the framing stages journalists have swaying power because they can focus their stories more on a particular issue while they tone down alternative viewpoints.

\section{Research Design}

This study's method was guided by the two concepts of framing- the media frames and the audience frames. According to Scheufele (1999) frames need to be considered schemes for both how media present news as well as how the audience comprehend and apply news. Therefore, it becomes important for researchers to distinguish between them in 
determining the best research methods (Colistra, 2012). In view of this, qualitative method through in-depth interview approach was adopted because it is a dyadic encounter between a researcher and participants which allows for gathering of account of lived experiences of ethnic group leaders. Creswell (2012) notes that interview enhances participants researcher interactions and aid research findings. Therefore, this study embraces interpretive perspective which places more importance on qualitative data value in a quest of knowledge (Kaplan and Maxwell, 1994) and providing contextual depth.

The sampling design was based on snowballing method due to sensitivity of the issue and difficulty of locating the participants (Creswell, 2012; Keyton, 2015). Series of in-depth interviews on 26 ethnic group leaders were conducted and data were codified and categorized in themes using NVIVO 8 software. Resulting from the interviews was the generation of coding frames which consisted of conceptualizing elements that explained the perspectives and lived experiences of the ethnic group leaders on ethnic conflicts in Nigeria. Then, subcategories were further developed in other to deepen the probing for rigorous and reliable findings. In the light of this, the following research questions were explored:

RQ1: Do newspaper frames of ethno-political issues stimulate ethnic groups' conflict frames?

$\mathrm{RQ2}$ : What are the perceptions about ethnic groups' role in conflict?

RQ3: What are the perceived solutions to ethnic conflict in Nigeria?

\section{Findings}

In line with the interpretive approach, the primary data analyzed thematically, were formed by interpretations, perception as well as meanings of the informants' verbal communication. In view of the study's main research objectives and research questions therefore, the following findings, for which each theme answered each research question, anchored on social construction of reality emerged.

\subsection{Newspaper framing: Stimulus of ethnic differences}

Newspaper framing, just like other communications, plays a key role in stimulating public expectations that influence whether conflict behavior or the tensions behind conflict are intensified or ameliorated (Price \& Stremlau, 2015). Therefore, in view of the increasing number of violent conflict in the world there is still need for more understanding of how modern internal conflicts are triggered (Puddephatt, 2011). More so, the need to understand conflict actors' perceptions about newspaper framing of ethnic conflict in Nigeria is imperative, especially with a view to establishing the impacts as well as solutions. Meanwhile, based on the interviews with ethnic group leaders, the following (figure 1 below) emerged as issues that bothered on newspaper framing which stimulate ethnic conflict in Nigeria.

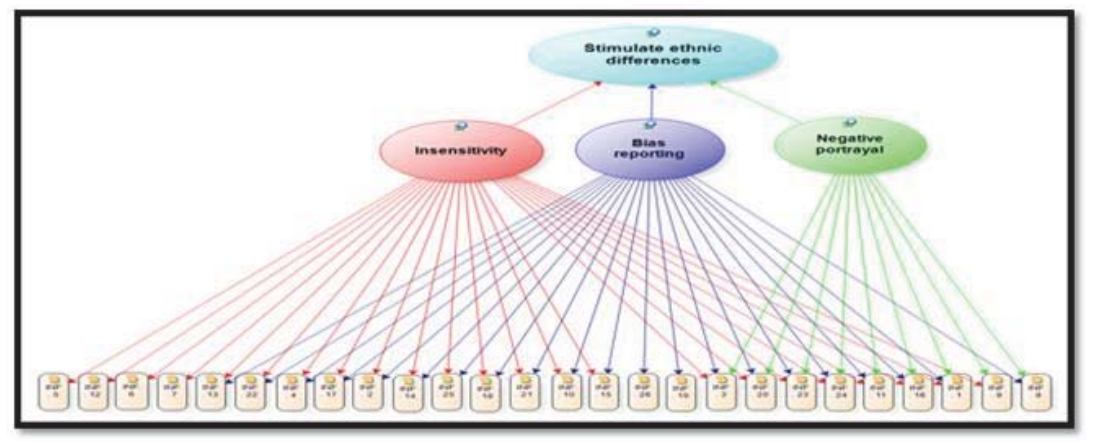

Figure 1: Ethnic group leaders' perceptions of newspaper framing role in conflict

\subsubsection{Insensitivity}

Media has been known to manipulate its influence over society through news reports, most of the time, sensationalized to the audiences. According to Maundu (2014) media insensitivity through inciting reports, sensationalized reports, and exaggeration of conflict issues comes into play when they propagates messages of intolerance or disinformation that 
manipulate public sentiment. The insensitive role played by Radio Mille Collines in Rwanda is one of the most appalling contemporary examples of media insensitivity that stimulate conflict (Howard, 2015). This concern on the insensitive role of the media especially newspapers in conflict was also expressed by the ethnic group leaders. Specifically, the informants accused newspapers of exaggeration, inciting and insensitivity framing to the detriment of one ethnic group against the other. For instance, Informant IB7, accused newspaper thus:

\begin{abstract}
Newspapers also contribute to this conflict by given unnecessary attention to statement that can cause conflict in the society...Nigeria newspapers are obsessed with conflict news. They so much like to blow issues beyond normal, they rely so much on rumour, unconfirmed facts (Inf. IB7).
\end{abstract}

Corroborating this perception, Informant 4, argued that newspapers are insensitive to issues of conflict. He claimed that newspapers, "exaggerate things and create tense environment. Most of what lead to conflict in Nigeria are those that newspapers were not sensitive to instead the media will exaggerate it, and give it prominence unnecessarily". Similar perception about newspapers insensitive framing on ethnic conflict was also expressed by Informant IJ25, who said, "newspapers increase tension among ethnic groups through their bias and insensitive reporting, politicize anything about ethnic in Nigeria".

\title{
4.1.2 Bias reporting/framing
}

Bias in media reporting is the unfairness or perceived partiality of journalists in the choice of events and stories that are reported and how they are covered which contravene the standards of journalism. Baron (2006) surveys point toward the fact that the public views the media as biased. Sometimes, according to Entman (2007) bias is identified from news that allegedly distorts or falsifies truth (distortion bias). At times referred to news that give special treatment to one group in a conflict and not giving the same treatment to the other side (content bias). At the same time, bias could be socio and ethno-political, where media owners, editors, or journalists report news that support particular interest (Baron, 2006). Similarly, ethnic group leaders interviewed gave their perceptions on the nature and impact of the media bias. For instance, Informant IB18, buttressed scholars' point of view by stating that:

The media can manipulate fact at time to favour some groups. They give support to whoever they are interested in. All these cause other to be angry. Reading through the newspapers I do come across many imbalance and bias stories about my ethnic group...newspaper role in some of the ethnic conflict is that they are bias (Inf. IB18).

Indicating similar perspective to the way that newspaper report issues concerning groups in Nigeria, Informant F26, stressed that, "newspapers through what they report give preference to ethnic differences. They support one ethnic group at the expense of the others". On the implication of the bias reporting on ethnic relation in Nigeria, Informant Y17, observed that, "Newspapers bias reporting is usually the motivating factor to some ethnic groups to take up arms against the others".

\subsubsection{Negative Portrayal}

Media negative portrayal which is also referred to as stereotype is the overgeneralizations and reporting in bad light the activities of a group with the purpose of creating certain negative image about the group (Holt, 2013). Most times, negative portrayal stimulate hatred and animosity among groups which may eventually result to conflict. Expressing similar perception, Informant H8 said, "I blame newspapers much is in the area of imbalance stories. They at times deliberately categorize a group as bad while portray other as good, whereas it is not so". Another ethnic leader, Informant IJ20 noted that "without getting our side of a story, they will just go ahead fabricating stories and lying against us".

\subsection{Attitudes of ethnic groups' role in ethnic conflict}

Nigerian has for some times been at the receiving end of an intense upsurge of ethnic groups militias (Agbu, 2004), whose attitudes have been causing turmoil. Presently, there are many militant divisions of ethnic groups who are armsbearing in Nigeria (Ikuteyijo \& Rotimi, 2012). Further to this, unfortunately the number of these groups grows daily while the government looks on helplessly at a loss on how to handle the problem. Probing to know the kind of attitudes of ethnic groups that stimulate conflict therefore, the study discovered, as the factors as indicated in the figure 2 below. 


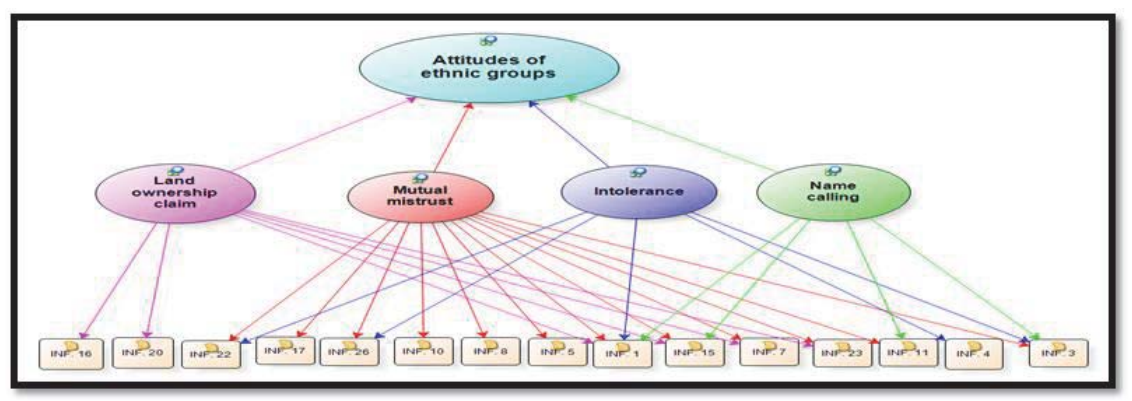

Figure 2: Attitudes of ethnic groups that stimulate conflict

\subsubsection{Mutual Mistrust}

Suspicion and mistrust have been the regular behavior of the major ethno-political structures in Nigeria (the Hausa Fulani of the North, the Ibo of the East, the Yoruba of the West and the ljaw/Niger Delta of the South South) as well as other ethnic groups that were carved by the colonial British in 1914. This has been attributed to one of the most devastating problem at the foundation of ethnic crises witnessed since the Nigeria independence in 1960 (Ajayi, 2014). In line with scholars in this regards, ethnic groups leaders across the major ethnic groups also expressed their opinions on the reasons for the mutual distrust and how it is stimulating ethnic conflict among them. Confirming this, one of the ethnic leader, Informant F3, stated the reality that, "we live under mutual suspicion. Every move of one ethnic group is seen as anti-others". Buttressing this claim, Informant H8, said, "Everybody is always prepare for each other. We suspect each other moves and actions". Again, on the reason for this widely mistrust among ethnic groups in Nigeria, Informant H11 observed that, "We seem to be too suspicious of each other on every issue in Nigeria".

\subsubsection{Intolerance/hostility}

The inability of ethnic groups to recognize, tolerate and accept each other's views is one of the accelerating factors of ethnic and political conflict in Nigeria. According to Halirru (2012) lack of tolerance behaviour is one of the reason for consistent conflict between the Nigerian Muslim and Christian, and most of the ethnic groups. In a similar tone Adelegan (2015) stressed that intolerance among groups has brought about the problem of state or place of origin, ethnicity, religion, tribalism, discrimination and related harms, all of which combined to create difficult barriers to Nigeria development. In line with scholars, ethnic leaders' perspectives described the level of intolerance among ethnic groups as a source of conflict on most occasions. For instance, Informant F26, stated that there is, "lack of intolerance among different ethnic groups that live together... and that level of tolerance among ethnic group leaders is low". Informants F3, and IB4 expressed similar views.

\subsubsection{Use of degrading words}

Name calling as well as degrading words are offensive or foul languages mostly used to qualify a person or group and customarily with numerous reason for their use (Slaatten \& Gabrys, 2014). This occurrence has been studied by a variety of academic disciplines such as anthropology, politics, child psychology and most commonly by disciplines that study propaganda methods. According to Aboud and Miller (2007), use of degrading words is one of the most common forms of mistreatment and intimidation which if left unchecked and condemned can stimulate hatred then conflict among groups and individuals.

The scholars' perspectives corroborate the perceptions of the interviewees of this study. For instance Informant F3, while stating some obscure causes of conflicts lamented the manner other ethnic groups treat them thus:

One of the reason for conflict between us is the fact that other tribe treat us like leper, and whenever we react they say so so people have come... They use all sort of names to castigate us. Some even call us cow, animal and murderers (Inf. F3). 
Similarly, another ethnic leader, Informant F1, also stated one of the reason for their conflict this way, "Some time they use derogatory name to qualified us and because some of (us) understand the language, we respond and from minor it becomes big issue that sometimes some people died in the clash".

\subsubsection{Land ownership claim}

Land disputes have stimulated a lot of conflicts across Nigeria (Igbinijesu, 2013). Over land ownership claim, many communities have repeatedly engaged in conflict. For instance, Land for the people according to Onwuzuruigbo (2009) was a cultural as well as spiritual asset, usually owned by families, clans, kinship groups and villages. This contention is reflected by the perceptions of this study's interviewees. For instance, Informant IB7 stressed that, "the usual cause of behavior that result to ethnic conflict are political position, economic interest, land issue and market issue". In relation to this view, another ethnic leader, Informant IJ20 noted that, "authority over who owns the land" is usually the cause of conflict.

\subsection{Perceived solutions to the ethnic conflict}

\subsubsection{Mutual interest}

As part of the solution to ethnic conflict, there is a need for ethnic groups to have far-reaching attitudes and understanding of how their actions would assist and serve the mutual interest of societies (Adelegan, 2015). Therefore, in an attempt to sustain peace and harmony in the society, both government and ethnic group leaders have to be mindful of others' interest as well as respect other people's interest. In line with the perspectives of ethnic group leaders, the following sub-themes: mutual tolerance, mutual trust and skeptic of newspaper stories emerged as the solutions to the ethnic conflicts.

Mutual tolerance: To achieve peace in any society with multiethnic groups, it will always require shaping and developing attitudes of tolerance, respect and understanding towards others. This informed the reason why tolerance is widely considered as an indispensable communal value for guaranteeing the cohesion of plural societies. For this reason, where people of different backgrounds, ethnic, cultures and religions are living together, promotion of tolerance and harmony has become very crucial and important, while nurturing mutual love and affection has become vital (Atif, 2010). In Nigeria for instance, the problem of state or place of origin, ethnicity, religion, and tribalism have combined to create barriers to development. People of different ethnic groups have not been able to give expression to politics without cynicism, and have not developed a spirit of tolerance and sportsmanship. As part of the solutions, some ethnic group leaders have identified some steps. For instance Informant F26 stated that "We should tolerate others who do business and study in our domain, improve on our tolerance for other ethnic groups". Similarly, Informant F2, disclosed that "Nigeria will have peace the moment we stop been selfish...So we should tolerate each other even in our differences. Similar perceptions were expressed by other ethnic leaders.

Skeptic of newspaper: Skepticism is an approach that is usually adopted in evaluating a claim when there is lack of trust between two or more individual or organizations. Meanwhile, in many societies, there has been an increasing subjective mood of alienation and mistrust toward the mainstream news media (Tsfati, 2003). Skepticism of media is apparent, for instance, in the sentiment that journalists have let down their professional requirements and presented slanted, imprecise, or inadequate information. The realization that being skeptical about newspapers' stories and the need to "Stop acting on rumours" are part of the solutions offered to reducing their impacts on the behavior of ethnic groups towards conflict as expressed by most of the ethnic group leaders such as Informants H8, F26 etc.

These worries about the unpopular role of newspapers before, during and after situation of conflict which is culminating into skepticism has also been a source of concern for media practitioners as well as scholars. According to Tsfati and Peri (2006), scholars, journalists and media analysts have been interpreting data from research as signifying a crisis of confidence between media audiences and conventional journalism.

Mutual trust: Mutual trust is a necessary pre-condition for the creation of societal benefits such as peace and harmony (Putnam, 2000). Among ethnic groups and people in any society generally, Post (2011) similarly stressed that mutual trust is a driving force for development and peaceful living. The depth and dimension of this mistrust according to Olufemi (2005) are what informed the emergence and popularity of ethnic militias such as the Arewa People's Congress (APC), Oodua People's Congress (OPC), Egbesu Boys, Bakassi Boys, ljaw Youths Congress and sundry militant organizations canvassing competing ethnic claims. However, in spite of all these efforts to minimize ethnocentric trends, and create cohesion considering the Nigerian cultural differences, the problem still persists. Therefore, the need for 
mutual trust was commonly offered as possible solution by the Informants such as Y16, IB23, F3 and IJ14 respectively.

\subsubsection{Government regulation and pro-activeness}

Government, at whatever level, has been described as a vital organ of conflict regulation and mediation because it is the only structure capable of marshalling enough legitimacy, resources and power to effectively manage conflicts (Onwuzuruigbo, 2009). However, the right strategies for the management of these conflicts have been a challenge since the time of the colonialists. The recurrent conflicts in Nigeria have called for re-examination of the strategies for their handling. In views of this, and as part of the solutions to ethnic conflicts, the need for government to be pro-active by regulating the activities of media, ethnic group and ownership of newspapers in Nigeria emerged as shown in the model below.

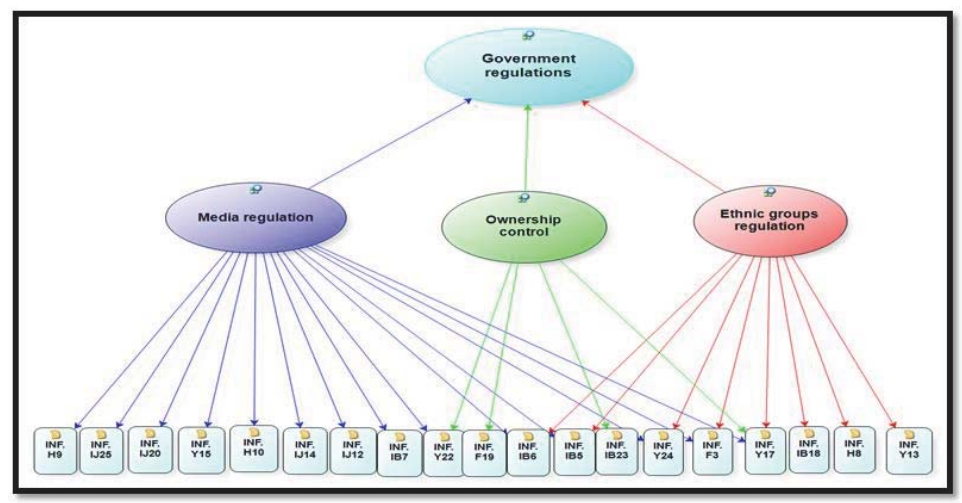

Figure 4: Government regulation and pro-activeness

Media regulation/self-regulation: Media self-regulation in the society is described as the combination of standards, ethics, application of the appropriate codes of behaviour that are necessary to support the freedom of expression and the process of how those behaviours will be monitored or held to account (Puddephat, 2011). Media self-regulation is imperative because anyone in the media is probable of being bias in what is presented as news. So, rather than government regulation, some scholars (Douglas, 1995) have called for absolute self-regulation, while some have advocated for full government regulation. Government regulation of the media would mean a government strengthening or instituting form of law or rules that will control, alter or influence media behaviour while self-regulation means that the industry or profession rather than the government is doing the regulation (Campbell, 1999). In line with this and as part of solutions to the ethnic conflicts in Nigeria, ethnic group leaders suggested media regulation as a solution. For instance, Informant IJ12, declared that, "Newspapers play a great role in ethnic conflict in the sense that call for reexamination of their role". Similarly, Informant H10 noted that as part of the solution, "the newspapers should be checked for their recklessness on issues concerning ethnic groups". Other Informants such as IJ14, Y15 and Y17 however called for either self-regulation or government regulation as long media can perform better.

\section{Discussion and Recommendations}

This study's findings have significantly contributed to the understanding of the helix of ethnic conflict behaviours of ethnic group leaders and the possible solutions to them. These are imperative because identification of influences toward such behaviours could create efficient strategies for governments and lessons for media and the ethnic leaders themselves.

For instance, the series of accusations against the Nigeria newspapers by the ethnic group leaders lead us to understand that the media are indeed insensitive and irresponsible on the issues of ethnic conflict. Also, that from bias framing of ethnic issues, newspapers have enormous power in setting ethnic differences which shape conflict behaviour. Another salient point emanating from these findings is that ethnic groups are too suspicious of each other moves, actions, inactions and that this is one of the reason for reaction to any move by other group. Built on these perceptions, it is evident that ethnic consciousness and intolerance has continued to impede the relationship among ethnic groups as well 
as progress of Nigeria. Due to high level intolerance for each other, every action and inaction is given ethnic coloration as a result conflict ensue. Consequently, inability to be tolerant of others' mistakes, excesses and misunderstanding undoubtedly is a potential catalyst for conflict and destruction. Arising from the solutions discovered, it is apparent that without mutual tolerance among ethnic groups, peace and harmony cannot be maintained in the society because specifically, lack of tolerance leads to hostility, conflict, and finally truncates the peace and security of society.

In view of this study's findings therefore, the following recommendation are imperative. Since it appears that the phenomenon of ethnic groups and their combative attitude will persist for a long time, there is an urgent need for constant monitoring, dialogue and informed public policy to minimize their negative impact on the country' maturing democracy. Also, the government should be concerned about how and what people receive as news on ethno-political issues as well as objectives of newspaper being established. In this regards, both government and media self-regulation should be strengthened.

\section{References}

Aboud, F., \& Miller, L. (2007). Promoting peer intervention in name-calling. South African Journal of Psychology, 37(4), 803-819.

Adisa, R. M., \& Abdulraheem, M. (2012). Mass Media and Conflicts in Nigeria: A Call for Peace Oriented Journalism. In Adeleke, B. L. \& ljaya, G. T. (eds.) General studies in the social sciences: Some fundamentals topics. General Studies Division, University of Ilorin, Ilorin, Nigeria. Pp 14-36.

Agbu, O. (2004). Ethnic militias and the threat to democracy in post-transition Nigeria (Vol. 127). Uppsala: Nordic Africa Institute.

Ajayi, J. O. (2014). Resurgence of Ethnic Crises and Instability in Nigeria. Research on Humanities and Social Sciences, 4(21), 44-55.

Arbour, L. (2014). "10 Conflicts to Watch in 2013" The International Crisis Group. Retrieved gth December, 2014 from http://www.crisis group.org/en/publication-type.

Atif, L. A. (2010). Importance of tolerance. Retrieved May 19, 2015 from http://www.timesofmalta.com/articles/view/20101226/opinion/ importance-of- tolerance.342594.

Baron, D. P. (2006). Persistent media bias. Journal of Public Economics, 90(1), 1-36.

Bienen, H. (2013). Political conflict and economic change in Nigeria. Routledge.

Bryant, J. \& Miron, D. (2004). Theory and research in mass communication. Journal of Communication 54(4): 662-704.

Campbell, A. J. (1999). Self-regulation and the media. Federal Communications Law Journal, 51(3).

Carpenter, S. (2007). U.S. Elite and Non-elite Newspapers' Portrayal of the Iraq War: A Comparison of Frames and Source Use. Journalism \& Mass Communication Quarterly 2007 84: 761 DOI: 10.1177/107769900708400407.

Caselli, F., \& Coleman, W. J. (2013). On the theory of ethnic conflict. Journal of the European Economic Association, 11(s1), 161-192.

Colistra, R. (2012). Shaping and Cutting the Media Agenda Television Reporters' Perceptions of Agenda-and Frame-Building and Agenda-Cutting Influences. Journalism \& Communication Monographs, 14(2), 85-146.

Creswell, J. W. (2012). Educational research: Planning, conducting, and evaluating quantitative and qualitative research. Fourth Edition. Pearson.

De Vreese, C. H. (2005). News framing: Theory and typology. Information Design Journal+ Document Design 13(1), 51-62.

De Vreese, C. H., Boomgaarden, H. G., \& Semetko, H. A. (2011). (In) direct Framing Effects: The Effects of News Media Framing on Public Support for Turkish Membership in the European Union. Communication Research, 38(2), 179-205. doi: 10.1177I 0093650210384934.

Douglas C. M. (1995). Federal Agency Use of Audited Self-Regulation as a Regulatory Technique, 47 Admin. L. REv. 171, 181-82 (1995); AYRES \& Braithwamie, supra note 14, at 110-12.

Entman, R. M. (1993). Framing: toward clarification of a fractured paradigm. Journal of Communication, 43, 51-59.

Entman, R. M. (2007). Framing bias: Media in the distribution of power. Journal of communication, 57(1), 163-173.

Erni, J. N. (2009). War, 'incendiary media' and international human rights law. Media, Culture \& Society 31(6): 867-886.

Eytan, A., Munyandamutsa, N., Nkubamugisha, P. M., \& Gex-Fabry, M. (2014). Long-term mental health outcome in post-conflict settings: Similarities and differences between Kosovo and Rwanda. International Journal of Social Psychiatry, 0020764014547 062.

Halliru, T. (2012). Ethno-Religious and Political Conflicts: A Study of North-Eastern Region of Nigeria (Doctoral dissertation, Universiti Utara Malaysia).

Holt, L. F. (2013). Writing the Wrong Can Counter-Stereotypes Offset Negative Media Messages about African Americans? Journalism \& Mass Communication Quarterly, 90(1), 108-125.

Howard, R. (2015). 4 Conflict-Sensitive Journalism. Communication and Peace: Mapping an Emerging Field, 62.

Hutchison, M. L. (2013). Tolerating Threat? The Independent Effects of Civil Conflict on Domestic Political Tolerance. Journal of Conflict Resolution.

Ibrahim, F., Pawanteh, L., Kee, C. P., Basri, F. K. H., Hassan, B. R. A., \& Amizah, W. W. (2011). Journalists and news sources: Implications on professionalism in war reporting. The Innovation Journal-The Public Sector Innovation Journal.

Igbinijesu, N. (2013). Discover Nigeria: 5 Causes of Conflict in Nigeria. Retrieved on March 25, 2015 from http://connectnigeria.com/ articles/2013/01/11/discover-nigeria-5-causes-of-conflict-in-nigeria.

Ikuteyijo, L., \& Rotimi, K. (2012). Community Partnership in Policing: The Nigerian Experience. The Police Journal, 85(2), 123-131. 
Irobi, E. G. (2005). Ethnic Conflict Management in Africa: A Comparative Case Study of Nigeria and South Africa. Beyond Interactivity. Retrieved 7 July, 2013 from http://www.beyondintractability.org/casestudy/irobi-ethnic.

Jeong, H. (2008). Understanding Conflict and Conflict Analysis. London: Sage.

Kalyango, J. \& Vultee, F. (2012). Public attitudes toward media control and incitement of conflicts in Eastern Africa. Media, War \& Conflict 5(2) 119-137.

Kaplan, B. and Maxwell, J. (1994). Qualitative research methods for evaluating computer information systems. In Evaluating health care information systems: Methods and Applications (Jay S.J., Ed), pp.45-68, Thousand Oaks, CA: Sage Publications.

Karnes, K. O. (2008). "What's the Story? Framing of Health Issues by the U.S. Centers for Disease Control and Prevention and Major Newspapers: A Qualitative Analysis" (2008). Communication Theses. Paper 36. http://digitalarchive.gsu.edu/communication_ theses.

Keyton, J. (2015). Communication research: Asking questions, finding answers (4th ed.). New York: McGraw Hill Higher Education.

Kostadinova, P., \& Dimitrova, D. V. (2012). Communicating policy change: Media framing of economic news in post-communist Bulgaria. European Journal of Communication, 27(2), 171-186. doi: 10.1177/0267323112449097.

Lecheler, S., \& de Vreese, C. H. (2012). News Framing and Public Opinion: A Mediation Analysis of Framing Effects on Political Attitudes. Journalism \& Mass Communication Quarterly, 89(2), 185-204. doi: 10.1177/1077699011430064.

Leung, L. (2009). Mediated violence as 'global news': co-opted 'performance' in the framing of the WTO. Media, Culture \& Society 31(2): 251-269.

Maundu, C. M. (2014). Conflict-sensitive reporting in Kenya's print media: a case of Tana River clashes (Doctoral dissertation, University of Nairobi).

McBeath, G. A. (1978). Political behavior of ethnic leaders. Comparative Politics, 393-417.

Munteanu, N. A. (2011). Mass-Media Role In Conflict Prevention. Land Forces Academy Review. Retrieved May $2^{\text {nd }} 2013$ from: http://www.readperiodicals.com/201101/2300043321.html\#ixzz2Ry0KxSM4.

Musa, A. \& Ferguson, N. (2013). Enemy framing and the politics of reporting religious conflicts in the Nigerian press. Media, War \& Conflict, 6(1), 7-20. DOI: 10.1177/1750635212469909.

Nnaemeka, T. I. (1991). 'Issue legitimation, Mass Media Functions and Public Knowledge of Social Issues'. (PhD dissertation, University of Minnesota).

Okwuchukwu, O. G. (2014). The Influence of Media Ownership and Control on Media Agenda Setting in Nigeria. International Journal of Humanities Social Sciences and Education (IJHSSE) Volume 1, Issue 7, 36-45.

Olubomehin, O. O. (2012). Ethnic and Communal Clashes in Nigeria: The Case of the Sagamu 1999 Hausa-Yoruba Conflict (Pp. 135149).

Olufemi, Kola (2005). "The Quest for 'True Federalism' and Political Restructuring: Prospects and Constraints." In Ebere Onwudiwe and Rotimi T. Suberu (eds.). Nigerian Federalism in Crisis: Critical Perspectives and Political Options. Ibadan: Programme on Ethnic and Federal Studies. University of Ibadan.

Onwuzuruigbo, I. (2009). Causes and Management of Intra-ethnic Conflicts in Aguleri and Umuleri Communities, Southeastern Nigeria (Doctoral dissertation, PhD thesis, Department of Sociology, University of Ibadan, Nigeria).

Onwuzuruigbo, I. (2010). Researching ethnic conflicts in Nigeria: the missing link. Ethnic and Racial Studies, 33(10), 1797-1813. doi: 10.1080/01419871003763304.

Osaghae, E. E., \& Suberu, R. T. (2005). A History of Identities, Violence and Stability in Nigeria: Centre for Research on Inequality, Human Security and Ethnicity, University of Oxford.

Post, D. (2011). Social Trust among Ethnic Minorities. Master thesis Research Master Social Cultural Science Radboud University Nijmegen.

Price, M. E. \& Stremlau, N. (2015). Strategic communications and the avoidance of violent conflict. In Hoffmann, J., \& Hawkins, V. (Eds.). Communication and Peace: Mapping an Emerging Field. Routledge.

Puddephatt, A. (2011). The Importance of Self-Regulation of the Media Upholding Freedom of Expression. CI Debates Series N.9 (ISSN 2176-3224) (p. 7). Brazil: UNESCO.

Putnam, R. D. (2000). Bowling Alone: The Collapse and Revival of American Community. New York: Simon \& Schuster.

Reese, S. D. (2001). Framing public life: A bridging model for media research. In S.D. Reese, O. H Gandy, and A. E Grant. Mahwah (Eds.), Framing public life: Perspectives on media and our understanding ofthe social world (pp.7-13). NJ: Lawrence Erlbaum Associates.

Sambanis, N., \& Shayo, M. (2013). Social identification and ethnic conflict. American Political Science Review, 107(2).

Scheufele, D. A. (1999). Framing as a theory of media effects. Journal of communication, 49(1), 103-122.

Seriki, A. A. (1993). The Nigerian Society and Religious Conflicts: A Retrospective View. In Religion and Service to Humanity, edited by R. D. Abubakre et al. llorin: Nigerian Association for the Study of Religion.

Serneels, P., \& Verpoorten, M. (2013). The impact of armed conflict on economic performance Evidence from Rwanda. Journal of Conflict Resolution, 0022002713515409.

Shoemaker, P. J. \& Reese, S. D. (1991). Mediating the Message: Theories of Influences on Mass Media Content. New York, NY: Longman, 137.

Slaatten, H., \& Gabrys, L. (2014). Gay-related name-calling as a response to the violation of gender norms. The Journal of Men's Studies, 22(1), 28-33.

Spencer, G. (2005). The Media and Peace: From Vietnam to the War on Terror. New York: Palgrave Macmillan. 
Tsfati, Y. (2002). The consequences of mistrust in the news media: Media skepticism as a moderator in media effects and as a factor influencing news media exposure.

Tsfati, Y., \& Peri, Y. (2006). Mainstream media skepticism and exposure to sectorial and extranational news media: The case of Israel. Mass Communication \& Society, 9(2), 165-187.

Van Gorp, B. (2007). The constructionist approach to framing: bringing culture back in. Journal of Communication 57 (2007) 60-78 2007 International Communication Association.

Wiegenstein, S. (2014). The Role of Newspapers in Shaping Public Opinion During the Period of Mormon Arrival in Quincy, 183839. Mor-mon Historical Studies, 2, 95-102.

Zhou, X. (2008). Cultural dimensions and framing the Internet in China: A cross-cultural study of newspapers' coverage in Hong Kong, Singapore, the US and the UK. International Communication Gazette 70(2): 117-136. 